\title{
Aquatic DOC export from subarctic Atlantic blanket bog in Norway is controlled by seasalt deposition, temperature and precipitation
}

\author{
Heleen A. de Wit • José L. J. Ledesma • \\ Martyn N. Futter
}

Received: 18 August 2015/Accepted: 6 January 2016/Published online: 21 January 2016

(C) The Author(s) 2016. This article is published with open access at Springerlink.com

\begin{abstract}
Comprehensive and credible peatland carbon budgets, needed for global carbon accounting, must include lateral aquatic organic carbon export. Here, we quantify aquatic dissolved organic carbon (DOC) export for an Atlantic bog in subarctic Norway, the Andøya peatland, and test for sensitivity to climatic drivers. Hydrology, DOC concentrations and DOC export were simulated for 2000-2013 using the process-based catchment model Integrated Catchments model for Carbon (INCA-C), calibrated to sitespecific water chemistry and hydrology (2011-2014) using readily-available data on temperature, precipitation and seasalt deposition. Measured streamwater DOC declined under seasalt episodes and was strongly positively related to temperature. Model calibrations successfully reproduced the water balance, variation in runoff $\left(\mathrm{R}^{2}=0.67\right.$; Nash-Sutcliffe model efficiency
\end{abstract}

Responsible Editor: J. M. Melack.

Electronic supplementary material The online version of this article (doi:10.1007/s10533-016-0182-z) contains supplementary material, which is available to authorized users.

H. A. de Wit $(\square)$

Norwegian Institute for Water Research (NIVA),

Gaustadalléen 21, 0349 Oslo, Norway

e-mail: heleen.de.wit@niva.no

\section{J. L. J. Ledesma · M. N. Futter}

Department of Aquatic Sciences and Assessment, Swedish University of Agricultural Sciences (SLU), Uppsala, Sweden
$\mathrm{NS}=0.67)$ and DOC concentrations $\left(\mathrm{R}^{2}=0.85\right.$; $\mathrm{NS}=0.84)$. The most sensitive model parameters related to temperature-sensitivity of DOC production and DOC (de)sorption sensitivity to seasalts. Model uncertainty related to parameter space was similar to interannual variation in DOC export. Mean annual modelled DOC export was $7.2 \pm 0.7 \mathrm{~g} \mathrm{C} \mathrm{m}^{-2}$ year $^{-1}$, roughly $35 \%$ of the net land-atmospheric $\mathrm{CO}_{2}$ exchange at Andøya from 2009 to 2012 (estimated elsewhere). Current and antecedent mean temperature and precipitation were strong drivers of seasonal modelled DOC export, implying that warmer and wetter summers will lead to more DOC export. Evaluation of similar climate impacts on net peatland carbon accumulation requires additional exploration of the climate-sensitivity of land-atmosphere fluxes of $\mathrm{CO}_{2}$ and methane. Process-based models are valuable tools to account for lateral DOC exports in carbon balances of northern peatlands, especially where longterm monitoring data are lacking.

Keywords Aquatic DOC export - Peatland . Climate Carbon balance $\cdot$ Atlantic subarctic blanket bog $\cdot$ Seasalt deposition

\section{Introduction}

Aquatic carbon fluxes are an important part of both boreal (de Wit et al. 2015) and global carbon cycles (Cole et al. 2007). Ecosystem carbon accumulation 
may be considerably overestimated when components of the net ecosystem carbon balance (NECB; Chapin et al. 2006) are not accounted for, including lateral aquatic export of dissolved organic carbon (DOC) and particulate organic carbon, dissolved inorganic carbon (DIC and $\mathrm{CO}_{2}$ ) and methane fluxes (Nilsson et al. 2008; Olefeldt et al. 2012; Randerson et al. 2002; Roulet et al. 2007; Yu 2012). This is especially important in northern peatlands, which are among the largest terrestrial carbon stores (Gorham 1991; Yu 2012). The fate of these carbon stores under climate change presents a potentially large positive climatic feedback (Dorrepaal et al. 2009).

Peatland formation and hydrology are strongly connected through an interplay of water-table dependent plant productivity and decay rates, and reduced hydrological conductivity with peatland depth; resulting in surprisingly stable accumulation rates over long time-scales (Belyea and Clymo 2001). However, peatland carbon accumulation may decline or even become negative under climate change when the balance shifts between growth and aerobic or anaerobic decomposition (Rennermalm et al. 2010; Wu and Roulet 2014). Because climate is a major control of aquatic carbon export in peatland-dominated catchments (Holden 2005), a better understanding of the interactions between temperature and precipitation on all components of peatland carbon balances is needed for a more robust quantification of the fate of peatland carbon stores under a future climate.

There are a few examples of complete or nearly complete NECBs for peatlands, where net ecosystem exchange (NEE), methane fluxes and aquatic carbon fluxes have all been quantified (Dinsmore et al. 2010; Juutinen et al. 2013; Koehler et al. 2011; Nilsson et al. 2008; Olefeldt et al. 2012; Roulet et al. 2007). Many more studies have quantified NEE for peatlands, but not aquatic carbon export, i.e., in subarctic (Aurela et al. 2002; Lund et al. 2015), boreal (Aurela et al. 2007, 2009; Peichl et al. 2014; Sagerfors et al. 2008), tropical (Hirano et al. 2012; Mezbahuddin et al. 2014), and temperate peatlands (Beetz et al. 2013; Campbell et al. 2014; Elsgaard et al. 2012; Lund et al. 2007; McVeigh et al. 2014). Despite the lack of quantification of key components of NECB, several studies claimed to quantify the carbon sink strength of these peatlands (Campbell et al. 2014; Hirano et al. 2012; Hommeltenberg et al. 2014).

Aquatic concentrations (and fluxes) of DOC in headwater streams are the result of catchment processes where DOC is produced from fresh and humified organic materials (Michalzik et al. 2001), sorbed and desorbed from solid phases by metal complexation and acidity (Neff and Asner 2001; Tipping et al. 1995), and displaced and leached by vertical and lateral water movement (Boyer et al. 1996; Ledesma et al. 2015). Atmospheric deposition of sulfate (Monteith et al. 2007) and chloride (Moldan et al. 2012) can lower DOC concentrations by suppressing organic matter solubility. Several models have managed to successfully describe DOC transport through soils taking into account most of the above processes (Michalzik et al. 2003; Neff and Asner 2001), except for the chemical control of sorption-desorption DOC dynamics (Dick et al. 2015). Process-based models have been developed specifically for peatlands carbon accumulation (Sulman et al. 2012; Webster et al. 2013; Wu et al. 2012), which include water table effects on various process rates, but usually without taking into account lateral fluxes of water and DOC.

The Integrated Catchments model for Carbon (INCA-C) (Futter et al. 2007, 2009) has been developed to simulate climate and deposition controls on surface water DOC concentrations and export. The model is process-based and simulates soil organic matter cycling controlled by temperature, soil moisture and chemistry in addition to vertical and lateral hydrological transport of DOC. INCA-C has been used for simulating DOC under present (Futter et al. 2007; Futter and de Wit 2008; Lepisto et al. 2014) and future (Futter et al. 2009; Oni et al. 2014) conditions at a range of headwater and larger catchments in Fennoscandia and Canada.

Here, we use INCA-C to quantify streamwater DOC concentrations and DOC export from an Atlantic, Norwegian subarctic bog between 2000 and 2013, and investigate the sensitivity of catchment DOC concentrations and export to climatic, chemical and hydrological factors. We demonstrate that our approach is suitable for adding lateral aquatic DOC fluxes to NECBs where DOC export measurements are unavailable. Available data on stream chemistry and hydrology for 2011-2014 were used to calibrate the model. We chose the period 2000-2013 to model DOC concentrations and export because it was the longest available period with climate and deposition data for full years. In addition, this time period includes the years for which NEE was quantified at Andøya (2009-2012) (Lund et al. 2015). 


\section{Materials and methods}

\section{Site description}

The study site $\left(69^{\circ} 08^{\prime} \mathrm{N}, 16^{\circ} 01^{\prime} \mathrm{E}\right)$ is located on the Andøya Island at the Atlantic coast of Norway, near Saura, north of the Arctic Circle (Fig. 1). The site will be referred to as the Andøya peatland instead of its more local name the 'Saura bog'. An eddy covariance system was installed in 2008 for the measurement of NEE of $\mathrm{CO}_{2}$ (Lund et al. 2015). The peatland is typical of the ombrotrophic, raised bogs that are common at Andøya (Buys 1992). The Andøya peatland is a concentric, raised Atlantic blanket bog dominated by thick hummocks interspersed with depressions, termed lawns or carpets. The vegetation is characterized by oligotrophic species including crowberry (E. nigrum), cloudberry ( $R$. chamaemorus), sedges (Carex spp.), cotton sedges (Eriophorum spp.), reindeer lichen (Cladonia spp.), peat mosses (Spaghnum spp.), and other bryophytes, as described in more detail for the nearby Sellevollmyra raised bog (Vorren et al. 2007). The bedrock underneath the peatland consists partly of Jurassic sedimentary rocks resting on a weathered granitic Precambrian basement (Lund et al. 2015).
Andøya has a mild climate, despite its location north of the Arctic Circle because of maritime influences from the Atlantic Ocean. Long-term mean annual temperature (MAT) and precipitation (1961-1990) are $3.6^{\circ} \mathrm{C}$ and $1060 \mathrm{~mm}$, respectively. February is the coldest month $\left(-2.2{ }^{\circ} \mathrm{C}\right)$ while July and August are the warmest months $\left(11^{\circ} \mathrm{C}\right)$.

The area with the eddy covariance tower is drained by a stream that connects with a peatland extraction site upstream to the northeast (Fig. 1). The likely impact on streamwater chemistry and hydrology from human disturbance compelled us to choose the stream directly adjacent to the $\mathrm{CO}_{2}$ flux monitoring catchment area for monitoring of aquatic carbon export. This peatland catchment is not disturbed by extraction, and is an oligotrophic, concentric, raised bog with similar vegetation and bedrock as the area used for $\mathrm{CO}_{2}$ flux monitoring. Thus, it is suitable for quantification of aquatic carbon export from the peatland area where NEE is measured.

The peatland catchment was delineated based on a digital elevation model (source Norwegian Mapping Authority) with $1 \mathrm{~m}$ vertical resolution and vegetation and topographical features (indicative of hydrological pathways and bog formations) from the aerial
Fig. 1 Map of catchment at Andøya. Aerial photograph obtained from Google Earth imagery (Image (C) 2015 Digital Globe), with modifications to illustrate the monitoring facilities

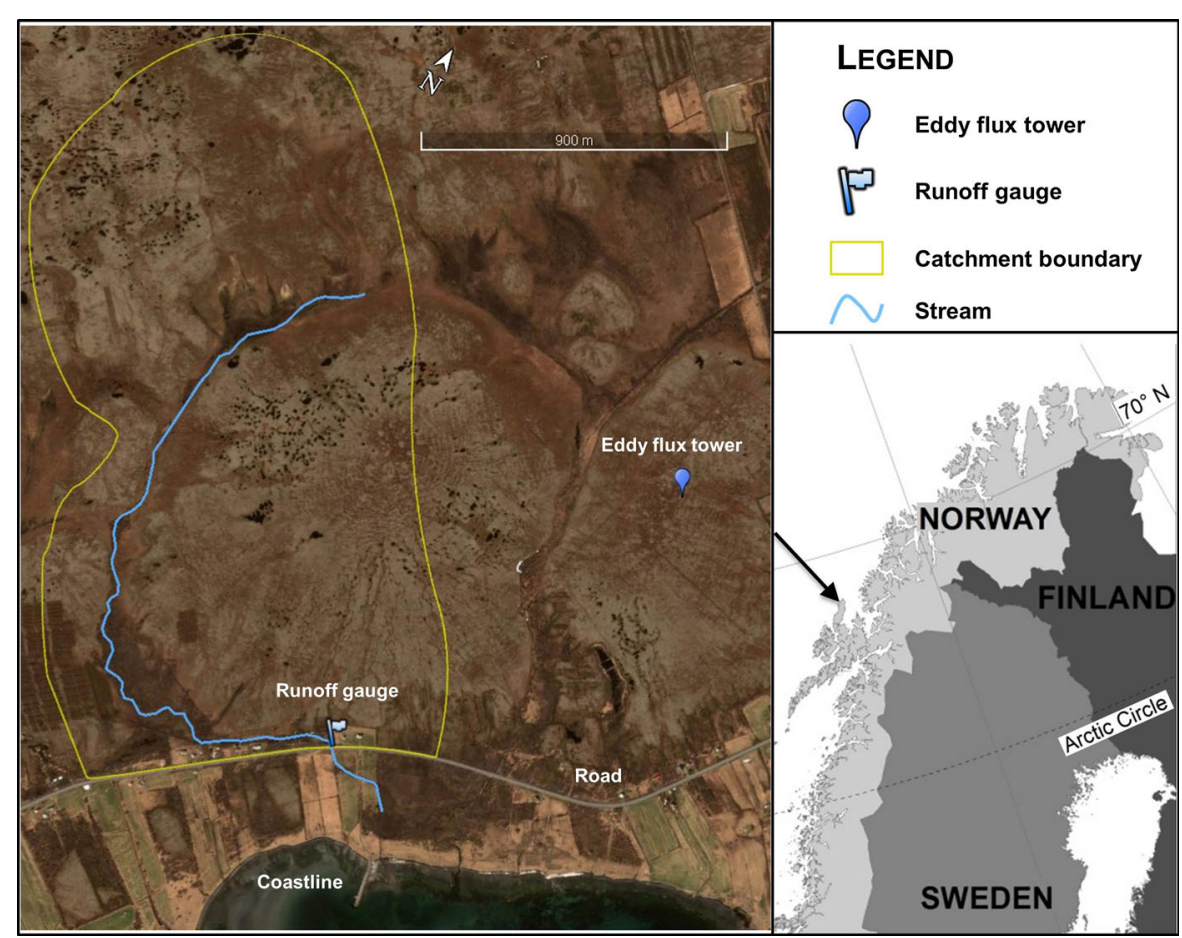


photograph, resulting in a $2.1 \mathrm{~km}^{2}$ area, with an uncertainty that we estimate to be circa $10 \%$. The peatland drains towards the east and south. The stream continues into a ditch which runs parallel to motorway 82 , at the southwest corner of the peatland, and passes underneath the road into a culvert that leads the stream to the sea. The road prevents discharge from the peatland from running directly to the sea, and thus the discharge monitored in the culvert can be assumed to give a correct estimate of runoff volume.

\section{Discharge}

Water flow velocity and water level were monitored from December 2012 in the culvert $(1.095 \mathrm{~m}$ in diameter) with an ISCO 2150 Area Velocity module using continuous wave Doppler technology to measure stream flow and a pressure transducer to measure water height. The pressure transducer was manually calibrated when monitoring started on 1st December 2012. Discharge is calculated automatically using diameter, flow, and height with the software Flowlink. Logging intervals were $15 \mathrm{~min}$, and data were sent twice weekly to the Norwegian Institute for Water Research (NIVA). Daily discharge was calculated as the sum of the 15 min interval observations.

\section{Streamwater chemistry}

The stream that drains the catchment was monitored for water chemistry from August 2011 until May 2014. Grab samples were taken by local observers, mostly at 2-3 week intervals and occasionally longer when deeps now hindered sampling. From January until May 2013, no samples were taken because the local observer was absent. The samples were taken according to monitoring procedures under the International Cooperative Programme on Assessment and Monitoring Effects of Air Pollution on Rivers and Lakes and the national acid deposition monitoring programme (Garmo et al. 2013; ICP Waters 2010), stored overnight in the dark at $4{ }^{\circ} \mathrm{C}$ before being sent by airmail to the accredited laboratory at NIVA. There, water samples were analyzed for $\mathrm{pH}$, conductivity, main anions $\left(\mathrm{SO}_{4}{ }^{2-}, \mathrm{Cl}^{-}, \mathrm{NO}_{3}^{-}\right)$, cations $\left(\mathrm{Ca}^{2+}, \mathrm{Mg}^{2+}, \mathrm{Na}^{+}\right.$, $\mathrm{K}^{+}$), and total organic carbon (TOC). Sixty percent of all samples were also analyzed for DOC (filtered by $0.45 \mu \mathrm{m})$. DOC was on average $96 \%$ of TOC, which justifies our assumption that TOC can be used as a proxy for DOC, and henceforth TOC will be referred to as DOC.

\section{Climate and deposition data}

Daily time series of temperature, precipitation and wind speed-related parameters (including average, minimum and maximum wind speed) were obtained for the period 1st January 2000-31st July 2014 from the Norwegian Meteorological Institute (Met Norway 2014) at the station 87110 in Andøya $\left(69^{\circ} 18^{\prime} \mathrm{N}\right.$, $16^{\circ} 07^{\prime} \mathrm{E}$ ), approximately $17 \mathrm{~km}$ north of the catchment outlet. Monthly time series of modelled wet seasalt deposition fluxes were available from the European Monitoring and Evaluation Programme (EMEP 2015) for the period 2000-2012, for the $50 \times 50 \mathrm{~km}^{2}$ grid cell where Andøya is located. Daily time series of atmospheric deposition are needed for modelling of DOC in INCA-C (see below). We constructed daily time series of seasalt $\left(\mathrm{Cl}^{-}\right)$deposition for January 2000 until July 2014 using the EMEP monthly deposition data (2000-2012) and daily weather data for 2000-July 2014 as follows. A multiple linear regression model using month of the year, temperature, precipitation, and the above mentioned wind speed-related parameters as predictors explained $89 \%$ of variation in monthly EMEP wet seasalt deposition for 2000-2012 (see supplementary information). As EMEP deposition data was not available for the latter part of the simulation, the model was used to construct monthly wet seasalt deposition for 2013-July 2014. To ensure internally consistent time series, the constructed deposition data were used as input for INCA-C for the whole simulation period (2000-July 2014). Monthly data were converted to daily values by assuming that deposition was evenly distributed throughout each month.

Hydrological modelling

The rainfall-runoff model PERSiST (Precipitation, Evapotranspiration and Runoff Simulator for Solute Transport; Futter et al. 2014) was used to simulate daily stream flow. PERSiST is a semi-distributed bucket-type model within a flexible framework that allows the modeler to specify the perceptual representation of the runoff generation process. The model 
generates the daily time series of soil moisture deficits (SMDs) and hydrologically effective rainfall (HER; precipitation net of evapotranspiration) needed as inputs to run INCA-C. As input data, PERSiST requires daily time series of air temperature and precipitation. In the model setup used here, precipitation is directed to the stream by direct runoff or into the soil, which is divided in two layers. Evapotranspiration leads to lowering of water storage, while water is transported either vertically (to the lower soil layer) or horizontally (to the stream). Key model parameters controlling soil hydrology in PERSiST are hydrological conductivity, soil depth, and runoff time constants.

\section{DOC modeling}

The organic carbon model INCA-C was used to simulate daily DOC concentrations and calculate monthly and annual DOC exports for 2000-2013. INCA-C is a dynamic, semi-distributed, process-based model that requires daily time series of precipitation, temperature, SMD, and HER (outputs from PERSiST, see above) to simulate daily stream flow (hydrological sub-model, a simplified version of PERSiST) and daily DOC concentrations (biogeochemical submodel) (Futter et al. 2007, 2009).The following processes are represented: (i) soil organic carbon (SOC) production through litter breakdown, (ii) temperature, moisture, and soil-solution chemistry dependent organic carbon sorption and desorption, and (iii) hydrologic controls on transport of DOC from soils to streamwaters. Key model parameters controlling DOC production and transport include soil thermal conductivity, temperature and soil moisture dependency of carbon processing rates including rates of DOC production, sorption and desorption in topsoil and subsoil, litter production, DOC production from litter, sensitivity of (de)sorption rates to soil-solution chemistry, and fraction of labile SOC of the SOC pool. For further details reference is made to Futter et al. (2007, 2009).

Model calibration strategy and uncertainty and sensitivity analyses

The model calibrations of PERSiST and INCA-C were based on minimizing the sum of squared differences between observed and modelled values. For both
PERSiST and INCA-C, preliminary manual calibrations using daily water discharge measurements (December 2012-July 2014) and measured DOC concentrations (August 2011-May 2014), respectively, were performed followed by a Monte Carlo (MC) exploration of parameter space and a final manual tuning of the best performing parameter set identified by MC analysis. Briefly, the MC analysis consisted of a number of iterations of a "hill climbing" algorithm which attempted to improve model goodness of fit through a series of directed jumps. Each iteration of the MC analysis consisted of a fixed number of model runs. The best performing parameter set and its associated goodness of fit coefficients from each iteration were retained for further analysis. The best performing parameter set from the entire analysis was used as input to the final manual calibration for both PERSiST and INCA-C. For the INCA-C analysis, all parameter sets were used to define posterior distributions for sensitivity analysis. As there was a range in goodness of fit for iterations of the $\mathrm{MC}$ analysis, the parameter sets with poor goodness of fit statistics (defined by setting a lower limit for model fit statistics) were not used in uncertainty estimation.

The calibration strategy for PERSiST followed the steps described by Futter et al. (2014). In short, an initial manual calibration identified credible parameter ranges that were subsequently explored with the MC procedure. Sensitive parameters identified during the manual calibration were allowed to vary by $\pm 30 \%$ during the $\mathrm{MC}$ analysis. Random starting points were drawn from the parameter space and compared to the best model performance, which was assessed using the sum of Nash-Sutcliffe (NS 1970), log NS and percent water balance statistics. This multi-parameter calibration scheme attempts to achieve a balance between fitting high flows (NS), low flows (log NS) and ensuring that cumulative modelled and observed flows are as similar as possible (percent water balance). When the random starting point was better than the best model performance, a predefined jump was applied to randomly perturb the parameter values, and repeated until no further improvement in model performance was obtained. The MC process was carried out in 100 iterations of 300 runs each and a single best-performing parameter set from the 100 loops was selected for final manual tuning. The final tuned parameter set was then used to generate time series of SMD and HER needed as input to the INCA-C simulations. 
The calibration strategy for INCA-C followed a slight adaptation to the approach described for PERSiST and by Ledesma et al. (2012). The initial manual calibration was done in two independent stages: first for the hydrological sub-model, and second for the biogeochemical sub-model. The parameters controlling the hydrological sub-model were fixed once the performance from manual calibration was similar to the best parameter set performance for PERSiST. Parameters for the biogeochemical sub-model were first calibrated manually, after which ranges for the MC analysis were set for each parameter individually by manual exploration of upper and lower values resulting in a DOC model performance of $\mathrm{NS}=0$. The MC tool was then run to find the best-performing dataset (from 100 loops of 300 runs). The final top performing 20 parameter runs (selected by setting a lower limit for model fit statistics) were retained for use in uncertainty estimation and the best performing parameter set was subject to a final manual refinement to further improve model performance.

The top performing (sum of NS statistics for DOC and flow) 20 parameter sets from the MC analysis were used to estimate uncertainties in daily DOC concentrations and annual fluxes between 2000 and 2013. Annual fluxes were calculated as the sum of daily fluxes, which in turn were estimated as the product of modelled daily DOC concentration and flow divided by catchment area. Uncertainty in model outputs that related to the parameter space was calculated as the $95 \%$ confidence intervals based on the 20 best performing runs, i.e., the daily mean DOC concentration (or annual flux) \pm 1.96 standard deviation.

Parameter sensitivity was assessed by comparing the ensemble of values from the 100 parameter sets identified during the MC analysis to a rectangular distribution based on the hypothesis that sensitive parameters would show non-rectangular posterior distributions as some regions of parameter space would be more conducive to good model performance than others. Sensitivity was quantified using a Kolmogorov-Smirnov (KS) test to compare the posterior to a rectangular prior. A significant $\mathrm{KS}$ statistic implied that variation of parameters within an a priori interval (identified by values for which NS statistic became 0) had significant effects on INCA-C simulated DOC.
Statistical analysis

Meteorological drivers of seasonal and annual DOC concentrations were evaluated using forward selection multiple stepwise regression (0.05 significance threshold). Variable selection was constrained as little as possible, except that the increase in explained variation upon each entered predictor had to be at least $1 \%$.The dependent variables were mean seasonal (yearly) DOC concentrations and the sum of seasonal (yearly) DOC export, where the seasons were defined as early winter (November and December, mostly discontinuous snow cover), winter (January-March, predominantly lowest temperatures and most stable snow cover), spring (April and May, snow melt occurs in this period), summer (June-August, months with highest temperatures) and autumn (September and October, typically higher precipitation but hardly any snow and colder temperatures). Eligible explanatory variables were summed discharge, summed precipitation and mean temperature for the given seasons and antecedent season, and per year.

\section{Results}

Temperature, precipitation and deposition (2000-2013)

MAT between 2000 and 2013 varied between 3.5 and $5.3{ }^{\circ} \mathrm{C}$, with an overall mean of $4.5{ }^{\circ} \mathrm{C}$ (Table 1). Both the mean and the range of MAT are above the longterm mean for $1961-1990$, which is $3.6{ }^{\circ} \mathrm{C}$ (see site description). On average, February was the coldest month $\left(-1.5^{\circ} \mathrm{C}\right)$, but with fluctuations above and further below freezing. In all winter months, episodic temperatures above zero occurred. July was on average the warmest month $\left(11.7^{\circ} \mathrm{C}\right)$ with relatively little variation between years. Annual precipitation varied between 777 and $1430 \mathrm{~mm}$, with a mean of $1086 \mathrm{~mm}$, similar to the long-term annual mean precipitation between 1961 and 1990, i.e., $1060 \mathrm{~mm}$. Precipitation was usually lowest from May to August and highest in September and October, with considerable interannual variation in monthly amounts (10 and $90 \%$ percentiles of monthly precipitation from May to August $<25$ and $>100 \mathrm{~mm}$, respectively). Annual seasalt deposition was between 5.1 and $9.7 \mathrm{~g}$ $\mathrm{Cl} \mathrm{m}^{-2}$, with a similar range in interannual variation as 
Table 1 Temperature, precipitation and deposition between 2000 and 2013

\begin{tabular}{|c|c|c|c|c|}
\hline & Unit & Mean & Minimum & Maximum \\
\hline \multicolumn{5}{|l|}{ Temperature } \\
\hline Annual & ${ }^{\circ} \mathrm{C}$ & 4.5 & 3.6 & 5.3 \\
\hline February & & -1.5 & -4.2 & 2.1 \\
\hline July & & 11.7 & 10.1 & 13.7 \\
\hline \multicolumn{5}{|l|}{ Precipitation } \\
\hline Annual & $\mathrm{mm}$ & 1086 & 777 & 1430 \\
\hline September & & 62 & 13 & 152 \\
\hline May & & 123 & 61 & 212 \\
\hline \multicolumn{5}{|l|}{$\mathrm{Cl}$ deposition } \\
\hline Annual & $\mathrm{g} \mathrm{m}^{-2}$ & 7.3 & 5.7 & 9.1 \\
\hline June & & 0.2 & 0.0 & 0.5 \\
\hline December & & 1.1 & 0.3 & 1.6 \\
\hline
\end{tabular}

Mean annual, minimum and maximum values are presented, in addition to values for the months with lowest and highest value for the given parameter

precipitation. Variation in seasonal seasalt deposition was considerable, mostly related to variation in wind speed (supplementary information), where westerly storms resulted in high seasalt deposition in winter months.

Monitored water chemistry and hydrology

The stream varied from slightly acidic $(\mathrm{pH}$ 6.0) to alkaline $(\mathrm{pH} 7.8)$ but was on average near-neutral (Table 2). The high alkalinity was accompanied by high concentrations of base cations and occurred mostly under low-flow conditions (data not shown). The peatland is underlain by Jurassic sedimentary rocks and the episodically high alkalinity is probably a sign of hydrological connectivity between the bedrock and the stream. Concentrations of DOC were on average $10 \mathrm{mg} \mathrm{L}^{-1}$ and fluctuated between 2.8 and 20 $\mathrm{mg} \mathrm{L}^{-1}$. DOC had a regular seasonal pattern with highest concentrations occurring during late summer (Fig. 2). In addition to this seasonal pattern, there was a strong effect of seasalt deposition, illustrated by the strong negative relationship between DOC and $\mathrm{Cl}^{-}$ (Fig. 3). The marine influences of seasalt deposition resulted in high concentrations of $\mathrm{Na}^{+}$and $\mathrm{Cl}^{-}$in the stream, where $\mathrm{Na}^{+}$was the dominating cation on an equivalent basis. The dominant anions, on an equivalent basis, were $\mathrm{Cl}^{-}$and carbonate ions $\left(\mathrm{HCO}_{3}{ }^{-}\right)$, the latter indicated by alkalinity. Concentrations of $\mathrm{SO}_{4}{ }^{2-}$ and $\mathrm{NO}_{3}^{-}$were on average below 17 and $6 \mu \mathrm{eq} \mathrm{L}^{-1}$.

Monitored discharge (December 2012-July 2014) varied strongly with peak flow between 25 and $30 \mathrm{~mm} \mathrm{day}^{-1}$ and low flow below $1 \mathrm{~mm}$ day $^{-1}$. Highest and lowest daily discharge occurred in winter, while summer discharge was less variable and lower than in the autumn. There were extended periods of low flow in winter, but these were interrupted by rainfall events or snowmelt episodes. The stream did not dry out during the observation period (Fig. 4).

Model performance and sensitivity analysis

The model calibrations were done as a combination of manual and MC analysis, optimizing on the NS statistic. The final MC process gave 100 parameter sets with corresponding model outputs. While each of the 100 parameter sets was generated using the same process, goodness of fit statistics varied considerably. Model performance was evaluated based on a number of test statistics (Table 3). For PERSiST, we selected the best parameter set, giving equal weight to the description of the water balance $(+3 \%)$, daily variation $\left(\mathrm{R}^{2}=0.67\right)$, peak flow $(\mathrm{NS}=0.67)$ and base flow ( $\log \mathrm{NS}=0.71$; Fig. 4). Similarly, the best parameter set for the biogeochemical sub-model in INCA-C was selected from the 100 parameter sets

Table 2 Summary (mean, standard deviation, minimum and maximum) of stream water chemistry for the study site (2011-2014, $\mathrm{N}=36)$

\begin{tabular}{lcccrrrrrrrr}
\hline & $\begin{array}{l}\mathrm{DOC} \\
\mathrm{mg} \mathrm{L}^{-1}\end{array}$ & $\mathrm{pH}$ & \multicolumn{1}{c}{$\begin{array}{l}\mathrm{Cl} \\
\mu \mathrm{eq} \mathrm{L}\end{array}$} & $\mathrm{SO}_{4}$ & $\mathrm{NO}_{3}$ & $\mathrm{Ca}$ & $\mathrm{Mg}$ & $\mathrm{Na}$ & $\mathrm{K}$ & $\mathrm{Alkalinity}$ \\
\hline Mean & 9.7 & 6.6 & 395 & 17 & 5.9 & 5.5 & 1.6 & 10.9 & 0.44 & 408 \\
Standard deviation & 4.0 & 0.5 & 167 & 21 & 4.6 & 3.7 & 0.8 & 4.1 & 0.30 & 375 \\
Minimum & 2.8 & 6.0 & 228 & 4 & 0.5 & 1.5 & 0.7 & 5.6 & 0.09 & 38 \\
Maximum & 18.7 & 7.8 & 1179 & 111 & 15.0 & 14.5 & 3.56 & 22.4 & 1.26 & 1483 \\
\hline
\end{tabular}


Fig. 2 Measured and simulated streamwater DOC concentrations at the Andøya catchment (2011-2014). The line shows simulated DOC concentrations from the best parameters set. The shaded area shows the $95 \%$ confidence interval of the DOC simulations based on the 20 best parameter sets

Fig. 3 Power-log regression model to predict stream DOC concentrations from stream $\mathrm{Cl}$ concentrations at the Andøya catchment (2011-2014, $\mathrm{N}=36$ )
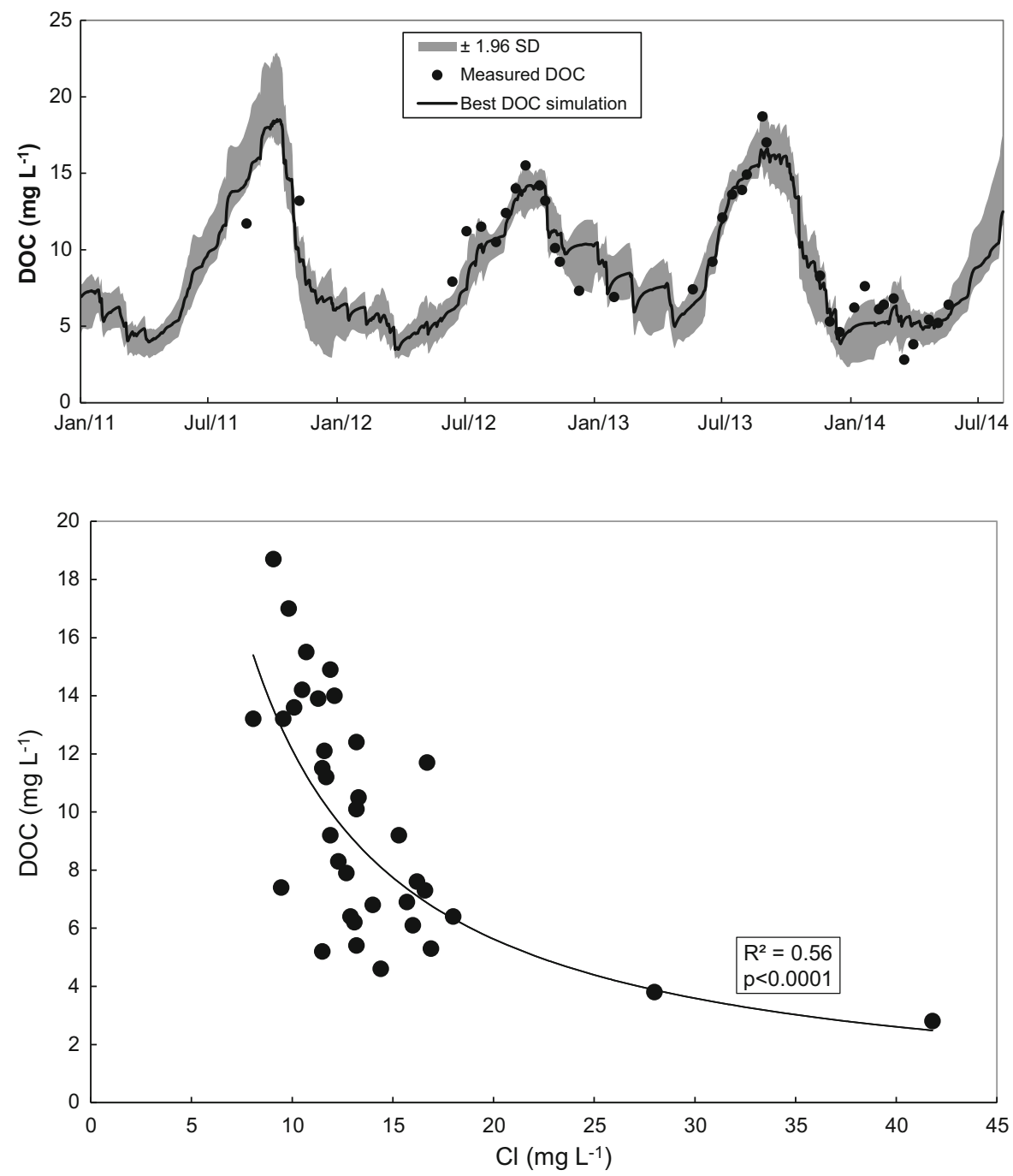

obtained from the MC analysis, based on an evaluation of variation and timing of peak DOC concentrations, and subsequently manually refined (Table 3 ). The hydrological sub-model within INCA-C for this parameter set gave a roughly equally successful calibration of peak stream flows as PERSiST. The dynamics $\left(\mathrm{R}^{2}=0.85\right)$ and concentration levels of stream DOC $(\mathrm{NS}=0.84)$ were captured well by the model.

The 20 best performing INCA-C parameter sets had NS $>0.65$ for flows and NS $>0.75$ for DOC. These parameter sets were retained for estimation of uncertainty bands for daily concentration and annual flux estimates. The simulated DOC concentrations from the best parameter set are presented together with the $95 \%$ confidence intervals based on INCA-C output from these 20 best parameter sets (Fig. 2). The upper and lower model uncertainty boundaries based on these standard deviations were narrow and most DOC observations fell within them, indicating good model performance with low uncertainty.

The list of statistically sensitive INCA-C biogeochemical sub-model parameters for simulation of DOC concentrations, identified with the MC analysis, is presented in Table 4 . The most sensitive parameters $\left(p<1^{-10}\right.$ ) were temperature-related, i.e., the thermal conductivity of the soil and a parameter controlling process-rate responses to a $10{ }^{\circ} \mathrm{C}$ change in soil temperature. The high dependency of modelled DOC on soil thermal properties is not surprising as process rates in the model all relate to temperature. The sensitive process rates were the parameter controlling 


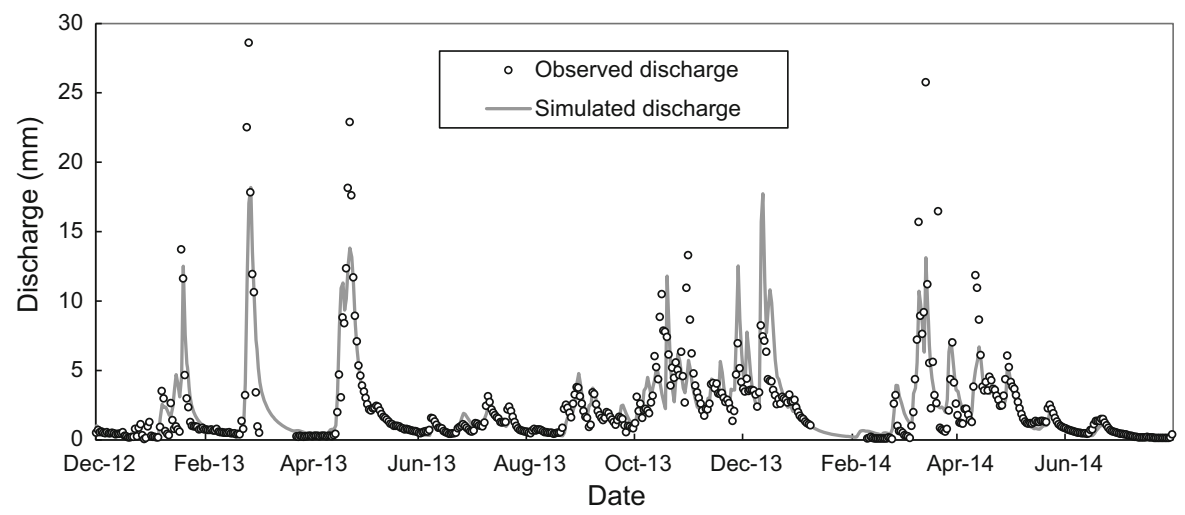

Fig. 4 Observed and PERSiST simulated daily discharge (mm) at the Andøya catchment (2012-2014)

Table 3 Goodness of model fit for discharge (PERSiST) and DOC (INCA-C) reported for best calibration parameter set

\begin{tabular}{llllll}
\hline Models & Variable & $\mathrm{R}^{2}$ & $\mathrm{NS}$ & Log NS & Sim./obs. \\
\hline PERSiST & Discharge & 0.67 & 0.67 & 0.71 & 1.03 \\
INCA-C & DOC & 0.85 & 0.84 & &
\end{tabular}

Ratio of simulated-observed mean annual water balance are included

$R^{2}$ coefficient of determination, NS Nash-Sutcliffe model efficiency

the DOC-sorption and -desorption rate in the upper soil layer to changes in chemistry $(p<0.0001)$, the SOC to DOC production rate in the upper layer $(\mathrm{p}<0.0005)$, and the DOC production rate from fresh litter $(p<0.0005)$. This sensitivity analysis suggests that streamwater DOC at Andøya is most sensitive to temperature, atmospheric chemistry (i.e., seasalt deposition), and (microbial) production of DOC, both from the existing SOC pool and from litter inputs.

\section{Model simulations}

Mean monthly DOC concentrations (2000-2013) simulated using the best model calibration had a strong seasonal signal and varied between $5.1 \mathrm{mg} \mathrm{L}^{-1}$ in April and $14.4 \mathrm{mg} \mathrm{L}^{-1}$ in September (Fig. 5). However, interannual variation in monthly DOC was large, as illustrated by the box plots, with ranges of $\sim 4 \mathrm{mg} \mathrm{L}^{-1}$ in April and $10 \mathrm{mg} \mathrm{L}^{-1}$ in the autumn months. Except for low discharge between May and August, there was no other strong seasonal signal in simulated discharge, although there was considerable interannual variation. Simulated median monthly discharge from May to August varied between 15 and $69 \mathrm{~mm} \mathrm{month}^{-1}$, while the variation from September to April was between 77 and $118 \mathrm{~mm}$ month $^{-1}$. Simulated mean monthly DOC export, however, followed a seasonal cycle with lowest export usually occurring between May and August (0.3-0.4 $\mathrm{g} \mathrm{C} \mathrm{m}^{-2}$ month $^{-1}$ ) and maximum export in September and October $\left(1.1 \mathrm{~g} \mathrm{C} \mathrm{m}^{-2}\right.$ month $^{-1}$; Fig. 5). The simulated seasonal DOC export pattern was related to the pattern in discharge and DOC concentrations. In November and December, simulated DOC export declined, following a similar development as DOC concentrations. In the summer months, DOC concentrations rose steadily while DOC export remained unaltered.

Mean annual DOC export between 2000 and 2013, simulated based on the best parameter set, was $7.2 \pm 0.7 \mathrm{~g} \mathrm{C} \mathrm{m}^{-2}$, with a maximum of $8.3 \mathrm{~g} \mathrm{C} \mathrm{m}^{-2}$ in 2013 and a minimum of $5.9 \mathrm{~g} \mathrm{C} \mathrm{m}^{-2}$ in 2009 (Fig. 6). The interannual variation was similar to the uncertainty interval of simulated annual DOC export $( \pm 15 \%)$, calculated as the $95 \%$ confidence interval of the mean DOC export from the 20 best performing parameter sets.

Drivers of DOC concentrations and export

Forward selection stepwise multiple regressions were performed to identify the best predictors of annual and seasonal DOC concentrations and fluxes. Annual discharge and annual precipitation were selected as the best predictors explaining the variation of simulated mean annual DOC concentration and annual DOC export for 2000-2013, respectively. Mean 
Table 4 List of significant ( $p<0.05$ ), sensitive parameters in INCA-C calibration, identified by Monte Carlo procedure

\begin{tabular}{|c|c|c|c|c|c|}
\hline Parameter description & Units & $\mathrm{p}$ value & Best value & A priori range & $\begin{array}{l}\text { A posteriori range } \\
(5-95 \text { Percentile })\end{array}$ \\
\hline Thermal conductivity of the soil & $\begin{array}{l}\mathrm{W} \mathrm{m} \mathrm{m}^{-1} \\
\mathrm{~K}^{-1}\end{array}$ & $<0.0001$ & 1.74 & $0-12.5$ & $0.075-2.71$ \\
\hline $\begin{array}{l}\text { Process-rate response to a } 10^{\circ} \mathrm{C} \text { soil } \\
\text { temperature change }\end{array}$ & - & $<0.0001$ & 2.97 & $0.085-9$ & $0.6-3.2$ \\
\hline $\begin{array}{l}\text { Response of DOC sorption/desorption } \\
\text { rate to changes in chemistry in topsoil }\end{array}$ & Day $^{-1}$ & $<0.0001$ & $2.9 \times 10^{-5}$ & $0-9.5 \times 10^{-5}$ & $\begin{array}{r}1.77 \times 10^{-6}- \\
5.55 \times 10^{-5}\end{array}$ \\
\hline $\begin{array}{l}\text { Production rate of DOC from SOC in } \\
\text { topsoil }\end{array}$ & Day $^{-1}$ & $<0.0005$ & $3.3 \times 10^{-4}$ & $\begin{array}{l}6.3 \times 10^{-5}- \\
3.5 \times 10^{-4}\end{array}$ & $1.4 \times 10^{-4}-3.5 \times 10^{-4}$ \\
\hline $\begin{array}{l}\text { Production rate of fresh litter to DOC in } \\
\text { direct runoff }\end{array}$ & Day $^{-1}$ & $<0.0005$ & $6.7 \times 10^{-4}$ & $0-0.012$ & $4.4 \times 10^{-4}-8.9 \times 10^{-3}$ \\
\hline
\end{tabular}

The a priori range was identified by values for which NS statistic became 0 and the a posteriori range was based on 100 parameter sets from Monte Carlo analysis

Fig. 5 Mean monthly DOC concentrations $\left(\mathrm{mg} \mathrm{C} \mathrm{L}^{-1}\right)$ (panel A), DOC export fluxes $\left(\mathrm{g} \mathrm{C} \mathrm{m}^{-2}\right)$ (panel $B$ ) and precipitation $(\mathrm{mm}$, panel C) for 2000-2013, simulated by INCA-C using the best parameter set. Box shows lower, median and upper quartile. Whiskers show $1.5 *$ interquartile range

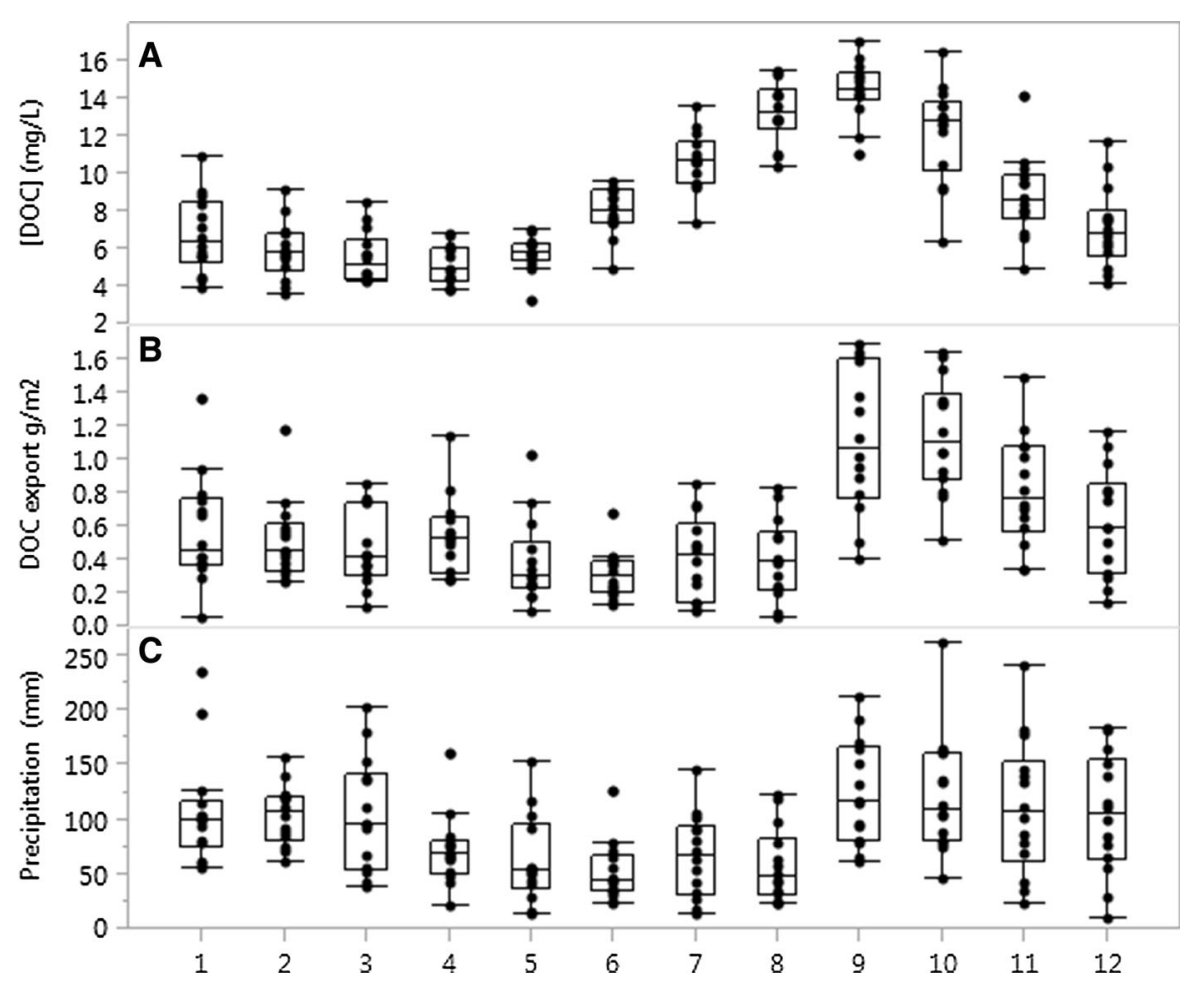

annual DOC concentrations related negatively to discharge $\left(\mathrm{R}^{2}=0.39, \mathrm{p}<0.05\right)$, while mean annual DOC export related positively to precipitation $\left(\mathrm{R}^{2}=0.63, \mathrm{p}<0.001\right)$. Thus, DOC concentrations were lower during wet years, while DOC export was highest. Current and antecedent season weather variables were the best predictors of seasonal DOC concentrations and fluxes (Table 5). The best models were found for seasonal DOC fluxes $\left(\mathrm{R}^{2}\right.$ between 0.84 and 0.98), while mean spring and summer DOC concentrations were most poorly explained $\left(\mathrm{R}^{2} 0.31\right.$ and 0.53 , respectively). For DOC concentrations, selected discharge or precipitation was always negatively related to DOC, while temperature had a positive effect on summer and autumn DOC, and negative on winter DOC. The negative effect of 
Fig. 6 Simulated annual DOC fluxes in $\mathrm{g} \mathrm{C} \mathrm{m}^{-2}$ at the Andøya catchment (2000-2013). The line shows simulated DOC fluxes from the best parameter set. The shaded area shows the $95 \%$ confidence interval of the DOC simulations based on the 20 best parameter sets

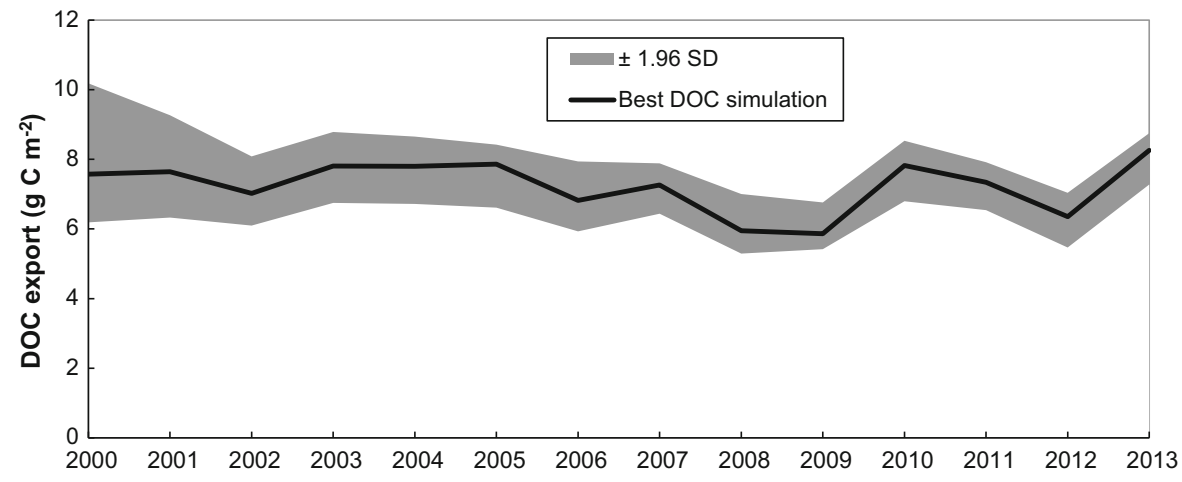

temperature on winter DOC may reflect effects of winter snowmelt episodes, while the positive effect of temperature on summer and autumn DOC could indicate temperature-driven production of DOC. Discharge or precipitation in the antecedent season related negatively to autumn to midwinter DOC concentration, possibly because DOC replenishment occurs at lower rates in winter.

For DOC fluxes, hydrological parameters were selected first in all seasons except autumn, where summer temperature was selected first. Current-season discharge promoted seasonal DOC fluxes, while antecedent-season discharge reduced seasonal DOC fluxes, possibly indicative of depletion of potentially leachable DOC stores for the following season. For early winter DOC flux, current and autumn temperature both contributed positively, but only after accounting for the effects of winter precipitation and autumn discharge.

\section{Discussion}

The simulated mean annual DOC export from the Andøya blanket bog of $7.2 \pm 0.7 \mathrm{~g} \mathrm{C} \mathrm{m}^{-2}$ year $^{-1}$ (2000-2013) was in the middle of the range of reported northern peatland DOC export (Table 6). Aquatic export of DOC in peat-dominated catchments is usually strongly promoted by precipitation (Olefeldt et al. 2013), similar to what we found in the statistical analysis of catchment DOC export, but in Table 6 the highest absolute DOC export is found in Scotland, which is not the site with the highest annual precipitation. Production of DOC per mm runoff reveals a variation between sites of 7 and $38 \mathrm{mg} \mathrm{C} \mathrm{mm}^{-1}$, where Andøya is found at the lower end. In a study of forested catchments on drained peatlands, harvestinduced DOC export correlated positively with site nutrient-richness (Nieminen et al. 2015), possibly implying a relationship between microbial activity and DOC production. Riverine aquatic DOC export per $\mathrm{m}^{2}$ drainage area in Norway was lowest in subarctic Norway, which coincided with a gradient of declining productivity (de Wit et al. 2015). Increased DOC export from peatland cores under higher temperatures was found in a field manipulation experiment (Fenner et al. 2007). Thus, factors like productivity, nutrient richness and temperature are all likely to contribute to variations in peatland DOC export but currently, the mechanistic understanding of these relationships remains inadequate.

The NEE was quantified for the Andøya peatland for 2009-2012 (Lund et al. 2015), ranging from -0.5 to $-35.7 \mathrm{~g} \mathrm{C} \mathrm{m}^{-2}$ year $^{-1}$, with mean annual NEE of $-19.5 \pm 18.3 \mathrm{~g} \mathrm{C} \mathrm{m}^{-2}$. Apparently, DOC export at Andøya has a lower interannual variability than NEE, i.e., $6.8 \pm 0.9 \mathrm{~g} \mathrm{C} \mathrm{m}^{-2}$ for 2009-2012. If only NEE and lateral DOC exports are considered (excluding methane fluxes, and aquatic fluxes of $\mathrm{CO}_{2}$ and DIC), including aquatic DOC export in the NECB for Andøya leads to reduction in net carbon uptake to $-12.6 \mathrm{~g} \mathrm{C} \mathrm{m}^{-2}$, switching the peatland in the coldest year (2010) from a (small) sink to a source of atmospheric carbon. Lund et al. (2015) found that $\mathrm{CO}_{2}$ uptake decreased under conditions of high vapor pressure deficit, indicative of low air moisture or relative drought, while no effect of reduced soil water content on NEE was found. However, in warmer and drier years the peatland was, perhaps surprisingly, a stronger annual sink for $\mathrm{CO}_{2}$ than in the year with temperature and precipitation close to the long-term average. The higher $\mathrm{CO}_{2}$ uptake was primarily driven 
Table 5 Summary of linear regression models based on forward multiple stepwise selection analysis for seasonal DOC concentrations and fluxes

\begin{tabular}{|c|c|c|c|c|c|}
\hline & \multicolumn{5}{|l|}{ Season } \\
\hline & $\begin{array}{l}\text { Midwinter } \\
\text { (January-March) }\end{array}$ & $\begin{array}{l}\text { Spring } \\
\text { (April-May) }\end{array}$ & $\begin{array}{l}\text { Summer } \\
\text { (June-August) }\end{array}$ & $\begin{array}{l}\text { Autumn } \\
\text { (September-October) }\end{array}$ & $\begin{array}{l}\text { Early winter } \\
\text { (November-December) }\end{array}$ \\
\hline \multicolumn{6}{|c|}{ DOC concentration } \\
\hline $\mathrm{T}$ current & $1(-2.51,0.029)$ & & & $3(3.21,0.009)$ & \\
\hline $\mathrm{T}$ antecedent & & & $1(3.72,0.003)$ & & \\
\hline \multicolumn{6}{|l|}{$\mathrm{P}$ current } \\
\hline $\mathrm{P}$ antecedent & $2(-2.43,0.033)$ & & & & $1(-3.73,0.003)$ \\
\hline Q current & & & & $1(-4.84,0.0007)$ & $2(-2.77,0.018)$ \\
\hline $\mathrm{Q}$ antecedent & & $1(-2.46,0.029)$ & & $2(-4.58,0.001)$ & \\
\hline $\mathrm{R}^{2}$ & 0.79 & 0.31 & 0.53 & 0.92 & 0.72 \\
\hline \multicolumn{6}{|l|}{ DOC flux } \\
\hline $\mathrm{T}$ current & & & & & $3(3.59,0.006)$ \\
\hline $\mathrm{T}$ antecedent & & & & $1(3.98,0.002)$ & $4(2.8,0.021)$ \\
\hline $\mathrm{P}$ current & & & $1(9.07,<0.0001)$ & $2(0.3 .91,0.002)$ & $1(13.27,<0.0001)$ \\
\hline \multicolumn{6}{|l|}{$\mathrm{P}$ antecedent } \\
\hline Q current & $2(6.25,<0.0001)$ & $1(9.39,<0.0001)$ & & & \\
\hline $\mathrm{Q}$ antecedent & $1(-6.38,<0.0001)$ & $2(-3.49,0.004)$ & & & $2(-7.44,<0.0001)$ \\
\hline $\mathrm{R}^{2}$ & 0.87 & 0.91 & 0.87 & 0.84 & 0.98 \\
\hline
\end{tabular}

Each cell gives the number in which variables were selected, and between parentheses the t-score and significance (p-value) of each parameter in a linear regression model, and the $\mathrm{R}^{2}$ for each model. Included explanatory variables were mean temperature, sum of precipitation, sum of discharge, for the current and antecedent season

by a stronger gross primary production, which dominated the effect of higher heterotrophic respiration. In warmer and drier years, aquatic DOC export would also be a smaller term in the peatland NECB, thus reinforcing the finding by Lund et al. (2015). However, the years 2009-2012 did not include an extreme drought. In a maritime climate, extreme droughts may be less likely to occur than in continental climates. Lund et al. (2015) concluded that Andøya retains its function as carbon sink under the present meteorological conditions. By including aquatic DOC export, it appears that the Andøya peatland can switch from a sink to a small source of atmospheric carbon under the present climate, even when carbon losses from methane and DIC are not considered. On average, DOC export was $35 \%$ of NEE at Andøya, which is at the high end of the range found elsewhere (Table 6).

Addressing the question of the influence of climate change on peatland carbon source or sink capacity clearly requires including aquatic DOC fluxes, but probably also requires a wider range of carbon accumulation studies with regard to peatland type, multi-annual studies and climatic gradients. A tool like the combined hydrological-biogeochemical model INCA-C (Futter et al. 2007) could be useful in this setting, as there are many studies of peatland NEE where quantification of aquatic carbon export is lacking, thus limiting the possibility to improve peatland NECBs (Aurela et al. 2002, 2007, 2009; Beetz et al. 2013; Campbell et al. 2014; Elsgaard et al. 2012; Hirano et al. 2012; Lund et al. 2007, 2015; McVeigh et al. 2014; Mezbahuddin et al. 2014; Peichl et al. 2014; Sagerfors et al. 2008). INCA-C can be used for quantification of aquatic DOC fluxes in catchments with limited observations for empirical quantification of DOC fluxes, and has been successfully calibrated for a number for small headwater catchments, with single and mixed land cover in various climate conditions (Futter and de Wit 2008; Futter et al. 2009).

The model goodness of fit of the INCA-C Andøya application was exceptionally high $\left(\mathrm{R}^{2}=0.85\right.$, $\mathrm{NS}=0.84$, Table 3) compared with other INCA-C applications (e.g., Futter et al. 2007, 2009; Futter and De Wit 2008; Oni et al. 2014), where $\mathrm{R}^{2}$ and NS 


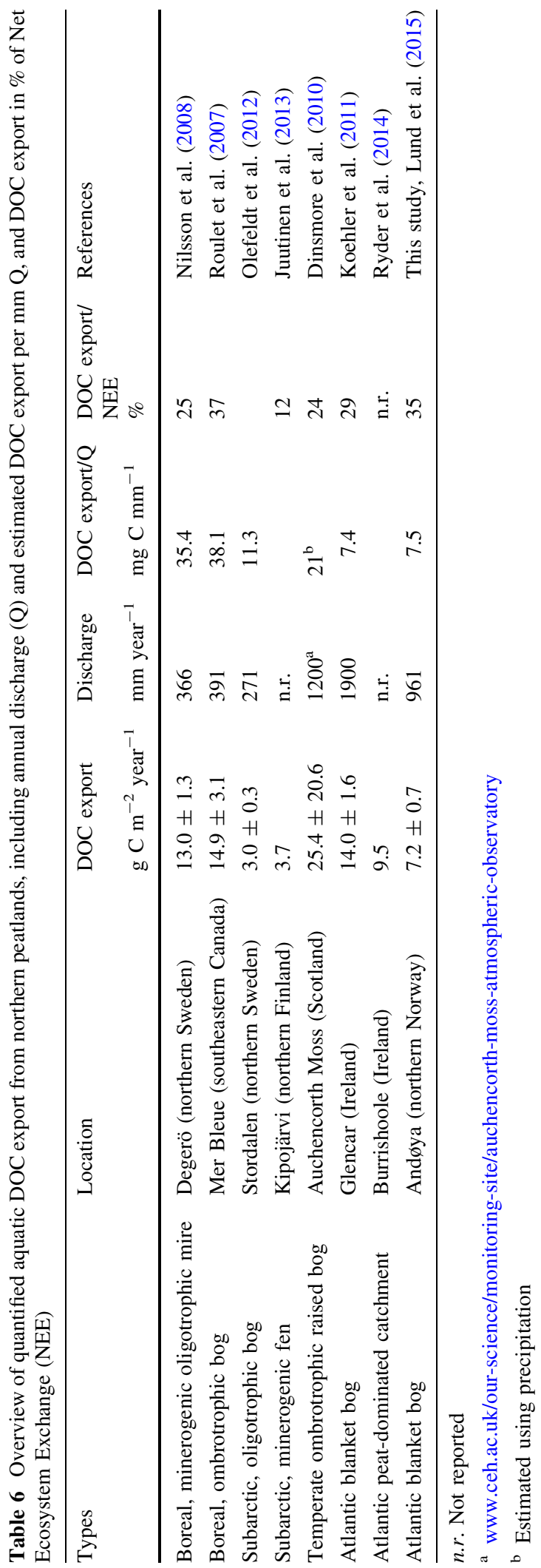

usually ranged between 0.3 and 0.5 . This is probably in part related to the limited number of observations compared with the other INCA-C applications. The potential to obtain good model fits is inversely related to the number of observations used for model calibration. It is trivial but true that complex models such as INCA-C or PERSiST can be calibrated to perfectly match a single observed value. The longer the period of record used for model calibration, the greater the likelihood of encountering extreme or unusual conditions which cannot be simulated using a single parameter set (Ledesma et al. 2012). However, it has been shown that longer calibration time series lead to better overall goodness of model fit (Larssen et al. 2007).

We explored the uncertainty in the model output in relation to the parameter space with an MC analysis, and found that the uncertainty was similar to interannual variations in DOC export. While MC approaches to estimate model uncertainty are very common (Beven 2006; Couture et al. 2015; Futter et al. 2007; Futter and De Wit 2008; Ledesma et al. 2012; Larssen et al. 2007; Oni et al. 2014), they are not truly objective. Every MC approach contains a number of hidden or explicit assumptions. For example, most Markov chain MC methods make strong assumptions about the parameter space and conditions for convergence. The MC approach used here is informed by the equifinality thesis (Beven 2006) which states that there is no single statistically best parameter set. The MC approach identifies an ensemble of credible parameter sets based on a defined exploration of parameter space. The "hill climbing" metaphor can be pursued further when describing the ensemble of parameter sets. In a mountain range, not all peaks have the same elevation. Using the approach presented here, while guaranteed to find local high points, makes no pretense of locating the highest peak in the mountain range. The parameter sets generated by this approach have a range of goodness of fit statistics but all share the property of being the best set of values identified by a particular set of model runs. Trimming the ensemble of parameter sets to use only the best performing subset will lead to more realistic uncertainty estimates as it will exclude predictions based on parameter sets that would have been rejected for poor performance during manual calibration. The final manual tuning of the best performing parameter set acknowledges the role of expert judgement in model use. Any automated 
calibration procedure has the potential to produce mathematically reasonable but scientifically implausible parameter values. For all but the very simplest of models, a final evaluation is needed to ensure the scientific credibility of model outputs. In the simulations presented here, the overall model performance was encouraging and the selection of sensitive parameters made biogeochemical sense.

Climatic factors and deposition chemistry are major controls of DOC concentrations at Andøya, as indicated by the inverse relationship between $\mathrm{Cl}^{-}$and DOC concentrations in the stream, by the selection of sensitive parameters in the INCA-C, i.e., temperature controls and sorption-sensitivity to atmospheric chemistry and by the statistical analysis of DOC concentrations and DOC export. The control of deposition chemistry on headwater DOC has been shown in monitoring time series of lake and streamwater DOC in boreal catchments (Monteith et al. 2007) and in experimental field manipulations (Moldan et al. 2012; Oulehle et al. 2013). Physico-chemical models provide a mechanistic explanation for this behavior, i.e., increased solubility of organic matter under conditions of lower conductivity and lower acidity, changing ion-binding and increasing negative charge of humic compounds, leading to a tendency to overcoming of inherent hydrophobicity of humic compounds (Tipping 1994). The WHAM model was successfully tested on soil-solution interactions in laboratory conditions (De Wit et al. 1999), and the concept of chemical controls on desorption behavior of DOC was successfully implemented in the INCA-C model (Futter and de Wit 2008).

The statistical exploration of the climatic controls of seasonal DOC concentrations and fluxes highlighted the importance of current and antecedent conditions of temperature and discharge. The negative effect of current-season's discharge on DOC concentrations agrees with the generally observed diluting effect of precipitation on DOC in peatland runoff, in contrast to upland soil runoff (Köhler et al. 2008). A positive relation between discharge and catchment aquatic DOC export is commonly found (Olefeldt et al. 2013; Raike et al. 2012). Temperature (antecedent and current) promoted DOC export in the autumn and early winter, suggesting that increased microbial activity under higher soil temperatures produces a higher store of potentially leachable DOC (Kalbitz et al. 2000; Tipping et al. 1999). Strong positive relationships between DOC concentrations and temperature were also found for three Norwegian catchments (De Wit et al. 2007; De Wit and Wright 2008). Soils can sustain high stores of potential DOC (Ledesma et al. 2015; Neff and Asner 2001), which can be emptied by excessive leaching (Haaland and Mulder 2010). An indication of depleted potentially leachable DOC stores may be found in the negative effect of antecedent discharge on autumn and early winter DOC export, when soil temperatures are too low for microbial replenishment of the potentially leachable carbon stores. An incubation study of organic-rich soils found that increased temperatures lead to a higher release of DOC, but also of $\mathrm{CO}_{2}$ (Neff and Hooper 2002). Thus, potential effects of higher temperatures combined with constant or increased precipitation are considerably higher aquatic export of DOC, and possibly lower net carbon accumulation depending on the effect of climate on productivity and methane emissions.

In this study, we show that the Andøya peatland is likely to be a weaker carbon sink than previously thought (Lund et al. 2015) and could in some years be a carbon source instead. Including estimates of methane emissions and losses from other carbon components by aquatic transport would be valuable for a more precise assessment of the peatland carbon sink strength. Our study is another example that aquatic export of DOC plays a significant role in peatland NECBs, more specifically in Atlantic bogs. In northern landscapes, peatland cover is a good predictor of catchment DOC export (Dillon and Molot 1997), and a key driver of riverine DOC fluxes at larger spatial scales (Raike et al. 2012). The role of lateral aquatic carbon fluxes in global (Cole et al. 2007) and regional (Buffam et al. 2011; de Wit et al. 2015) carbon budgets is large and conceptually easy to grasp (i.e., Chapin et al. 2006). However, terrestrial carbon fluxes have different sensitivities to environmental drivers than aquatic carbon fluxes. The former might be more sensitive to temperature and disturbance (i.e., Schlesinger and Andrews 2000) while the latter may be most sensitive to drought and precipitation (Olefeldt et al. 2013). The integrated effect of environmental change on terrestrial carbon sink capacity, where lateral carbon export is accounted for, will be increasingly hard to predict going from single land cover ecosystems such as the Atlantic bog in our study, to multiple land cover and land 
management regions as presented in Buffam et al. (2011), de Wit et al. (2015) and Christensen et al. (2007). Peatlands may be highly suitable for investigation of differential sensitivity of terrestrial and aquatic fluxes to environmental change, because conceptual fluxes and measurements can be done in a consistent way (Chapin et al. 2006). Our results lead us to strongly advocate that all peatland carbon balance studies include quantification of aquatic DOC fluxes and that there is a large potential for studying climate sensitivity of carbon fluxes in multiannual peatland carbon balances.

Acknowledgments Research at Andøya peatland was made possible through Grants from the Stiftelsen Fondet for Jord-og Myrundersøkelser (Foundation for Investigation of Soil and Peat, in Ås, Norway) and the Norwegian Institute for Water Research. This work profited from the Top Level Research Initiative Collaborative Project financed by Nordforsk (Domqua, 60501) and from the Ecco project (224779/E10), financed by the Norwegian Research Council. Logistic and technical support from Uta Brandt (NIVA) and the Andøya Rocket Range is gratefully acknowledged. We would like to thank Yan Lin (NIVA) for preparation of Fig. 1 and Mats Nilsson for valuable reviewer comments.

Open Access This article is distributed under the terms of the Creative Commons Attribution 4.0 International License (http:// creativecommons.org/licenses/by/4.0/), which permits unrestricted use, distribution, and reproduction in any medium, provided you give appropriate credit to the original author(s) and the source, provide a link to the Creative Commons license, and indicate if changes were made.

\section{References}

Aurela M, Laurila T, Tuovinen JP (2002) Annual $\mathrm{CO}_{2}$ balance of a subarctic fen in northern Europe: importance of the wintertime efflux. J Geophys Res Atmos 107(D21):ACH 17-1

Aurela M, Riutta T, Laurila T, Tuovinen JP, Vesala T, Tuittila ES, Rinne J, Haapanala S, Laine J (2007) $\mathrm{CO}_{2}$ exchange of a sedge fen in southern Finland-the impact of a drought period. Tellus B 59(5):826-837

Aurela M, Lohila A, Tuovinen JP, Hatakka J, Riutta T, Laurila T (2009) Carbon dioxide exchange on a northern boreal fen. Boreal Environ Res 14(4):699-710

Beetz S, Liebersbach H, Glatzel S, Jurasinski G, Buczko U, Hoeper H (2013) Effects of land use intensity on the full greenhouse gas balance in an Atlantic peat bog. Biogeosciences 10(2):1067-1082

Belyea LR, Clymo RS (2001) Feedback control of the rate of peat formation. Proc R Soc B 268(1473):1315-1321

Beven K (2006) A manifesto for the equifinality thesis. J Hydrol 320(1):18-36
Boyer EW, Hornberger GM, Bencala KE, McKnight D (1996) Overview of a simple model describing variation of dissolved organic carbon in an upland catchment. Ecol Model 86(2-3):183-188

Buffam I, Turner MG, Desai AR, Hanson PC, Rusak JA, Lottig NR, Stanley EH, Carpenter SR (2011) Integrating aquatic and terrestrial components to construct a complete carbon budget for a north temperate lake district. Glob Change Biol 17(2):1193-1211

Buys E (1992) Mire morphology, vegetation and hydrochemistry of the Andmyran Mire Reserve. Tromura Naturvitenskap. Troms $\emptyset$ University, Troms $\varnothing$, pp 1-164

Campbell DI, Smith J, Goodrich JP, Wall AM, Schipper LA (2014) Year-round growing conditions explains large $\mathrm{CO}_{2}$ sink strength in a New Zealand raised peat bog. Agric For Meteorol 192:59-68

Chapin FS, Woodwell GM, Randerson JT, Rastetter EB, Lovett GM, Baldocchi DD, Clark DA, Harmon ME, Schimel DS, Valentini R, Wirth C, Aber JD, Cole JJ, Goulden ML, Harden JW, Heimann M, Howarth RW, Matson PA, McGuire AD, Melillo JM, Mooney HA, Neff JC, Houghton RA, Pace ML, Ryan MG, Running SW, Sala OE, Schlesinger WH, Schulze ED (2006) Reconciling carbon-cycle concepts, terminology, and methods. Ecosystems 9(7):1041-1050

Christensen TR, Johansson T, Olsrud M, Strom L, Lindroth A, Mastepanov M, Malmer N, Friborg T, Crill P, Callaghan TV (2007) A catchment-scale carbon and greenhouse gas budget of a subarctic landscape. Philos Trans R Soc A 365(1856):1643-1656

Cole JJ, Prairie YT, Caraco NF, McDowell WH, Tranvik LJ, Striegl RG, Duarte CM, Kortelainen P, Downing JA, Middelburg JJ, Melack J (2007) Plumbing the global carbon cycle: integrating inland waters into the terrestrial carbon budget. Ecosystems 10(1):171-184

Couture RM, De Wit HA, Tominaga K, Kiuru P, Markelov I (2015) Oxygen dynamics in a boreal lake responds to longterm changes in climate, ice phenology and DOC inputs. J Geophys Res Biogeosci. doi:10.1002/2015JG003065

De Wit HA, Wright RF (2008) Projected stream water fluxes of $\mathrm{NO}_{(3)}$ and total organic carbon from the Storgama headwater catchment, Norway, under climate change and reduced acid deposition. Ambio 37(1):56-63

De Wit HA, Kotowski M, Mulder J (1999) Modeling aluminum and organic matter solubility in the forest floor using WHAM. Soil Sci Soc Am J 63(5):1141-1148

De Wit HA, Mulder J, Hindar A, Hole L (2007) Long-term increase in dissolved organic carbon in streamwaters in Norway is response to reduced acid deposition. Environ Sci Technol 41(22):7706-7713

De Wit HA, Austnes K, Hylen G, Dalsgaard L (2015) A carbon balance of Norway: terrestrial and aquatic carbon fluxes. Biogeochemistry 123(1-2):147-173

Dick JJ, Tetzlaff D, Birkel C, Soulsby C (2015) Modelling landscape controls on dissolved organic carbon sources and fluxes to streams. Biogeochemistry 122(2-3):361-374

Dillon PJ, Molot LA (1997) Effect of landscape form on export of dissolved organic carbon, iron, and phosphorus from forested stream catchments. Water Resour Res 33(11):2591-2600 
Dinsmore KJ, Billett MF, Skiba UM, Rees RM, Drewer J, Helfter C (2010) Role of the aquatic pathway in the carbon and greenhouse gas budgets of a peatland catchment. Glob Change Biol 16(10):2750-2762

Dorrepaal E, Toet S, van Logtestijn RSP, Swart E, van de Weg MJ, Callaghan TV, Aerts R (2009) Carbon respiration from subsurface peat accelerated by climate warming in the subarctic. Nature 460(7255):616-619

Elsgaard L, Gorres C-M, Hoffmann CC, Blicher-Mathiesen G, Schelde K, Petersen SO (2012) Net ecosystem exchange of $\mathrm{CO}_{2}$ and carbon balance for eight temperate organic soils under agricultural management. Agric Ecosyst Environ 162:52-67

EMEP, European Monitoring and Evaluation Programme. http://www.emep.int/. Accessed 18 Jan 2015

Fenner N, Freeman C, Lock MA, Harmens H, Reynolds B, Sparks T (2007) Interactions between elevated $\mathrm{CO}_{2}$ and warming could amplify DOC exports from peatland catchments. Environ Sci Technol 41(9):3146-3152

Futter MN, de Wit HA (2008) Testing seasonal and long-term controls of streamwater DOC using empirical and processbased models. Sci Total Environ 407(1):698-707

Futter MN, Butterfield D, Cosby BJ, Dillon PJ, Wade AJ, Whitehead PG (2007) Modeling the mechanisms that control in-stream dissolved organic carbon dynamics in upland and forested catchments. Water Resour Res 43(2): 16

Futter MN, Forsius M, Holmberg M, Starr M (2009) A longterm simulation of the effects of acidic deposition and climate change on surface water dissolved organic carbon concentrations in a boreal catchment. Hydrol Res 40(2-3):291-305

Futter MN, Erlandsson MA, Butterfield D, Whitehead PG, Oni SK, Wade AJ (2014) PERSiST: a flexible rainfall-runoff modelling toolkit for use with the INCA family of models. Hydrol Earth Syst Sci 18(2):855-873

Garmo Ø, Skancke L, Høgåsen T (2013) The Norwegian monitoring programme for long-range transported air pollutants. Annual report-water chemical effects 2012. NIVA report 6515-2013, Norwegian Environment Agency TA 3033/2013 (in Norwegian, with English summary)

Gorham E (1991) Northern peatlands-role in the carbon-cycle and probably responses to climate warming. Ecol Appl 1(2):182-195

Haaland S, Mulder J (2010) Dissolved organic carbon concentrations in runoff from shallow heathland catchments: effects of frequent excessive leaching in summer and autumn. Biogeochemistry 97(1):45-53

Hirano T, Segah H, Kusin K, Limin S, Takahashi H, Osaki M (2012) Effects of disturbances on the carbon balance of tropical peat swamp forests. Glob Change Biol 18(11):3410-3422

Holden J (2005) Peatland hydrology and carbon release: why small-scale process matters. Philos Trans R Soc A 363(1837):2891-2913

Hommeltenberg J, Schmid HP, Drosler M, Werle P (2014) Can a bog drained for forestry be a stronger carbon sink than a natural bog forest? Biogeosciences 11(13):3477-3493

ICP Waters (2010) ICP waters programme manual 2010. ICP waters report 105/2010, NIVA report 6074-2010. Norwegian Institute for Water Research
Juutinen S, Valiranta M, Kuutti V, Laine AM, Virtanen T, Seppa H, Weckstrom J, Tuittila ES (2013) Short-term and longterm carbon dynamics in a northern peatland-stream-lake continuum: a catchment approach. J Geophys Res Biogeosci 118(1):171-183

Kalbitz K, Solinger S, Park JH, Michalzik B, Matzner E (2000) Controls on the dynamics of dissolved organic matter in soils: a review. Soil Sci 165(4):277-304

Koehler AK, Sottocornola M, Kiely G (2011) How strong is the current carbon sequestration of an Atlantic blanket bog? Glob Change Biol 17(1):309-319

Köhler SJ, Buffam I, Laudon H, Bishop KH (2008) Climate's control of intra-annual and interannual variability of total organic carbon concentration and flux in two contrasting boreal landscape elements. J Geophys Res Biogeosci 113(G3): 12

Larssen T, Høgåsen T, Cosby BJ (2007) Impact of time series data on calibration and prediction uncertainty for a deterministic hydrogeochemical model. Ecol Model 207(1):22-33

Ledesma JLJ, Köhler SJ, Futter MN (2012) Long-term dynamics of dissolved organic carbon: implications for drinking water supply. Sci Total Environ 432:1-11

Ledesma JLJ, Grabs T, Bishop KH, Schiff SL, Köhler SJ (2015) Potential for long-term transfer of dissolved organic carbon from riparian zones to streams in boreal catchments. Glob Change Biol. doi:10.1111/gcb.12872

Lepisto A, Futter MN, Kortelainen P (2014) Almost 50 years of monitoring shows that climate, not forestry, controls longterm organic carbon fluxes in a large boreal watershed. Glob Change Biol 20(4):1225-1237

Lund M, Lindroth A, Christensen TR, Strom L (2007) Annual $\mathrm{CO}_{2}$ balance of a temperate bog. Tellus B 59(5):804-811

Lund M, Bjerke JW, Drake BG et al (2015) Low impact of dry conditions on the $\mathrm{CO}_{2}$ exchange of a Northern-Norwegian blanket bog. Environ Res Lett 10(2):13

McVeigh P, Sottocornola M, Foley N, Leahy P, Kiely G (2014) Meteorological and functional response partitioning to explain interannual variability of $\mathrm{CO}_{2}$ exchange at an Irish Atlantic blanket bog. Agric For Meteorol 194:8-19

Met Norway, Norwegian Meteorological Institute. http:// eklima.met.no/. Accessed 2 Oct 2014

Mezbahuddin M, Grant RF, Hirano T (2014) Modelling effects of seasonal variation in water table depth on net ecosystem $\mathrm{CO}_{2}$ exchange of a tropical peatland. Biogeosciences 11(3):577-599

Michalzik B, Kalbitz K, Park JH, Solinger S, Matzner E (2001) Fluxes and concentrations of dissolved organic carbon and nitrogen - a synthesis for temperate forests. Biogeochemistry 52(2):173-205

Michalzik B, Tipping E, Mulder J, Lancho JFG, Matzner E, Bryant CL, Clarke N, Lofts S, Esteban MAV (2003) Modelling the production and transport of dissolved organic carbon in forest soils. Biogeochemistry $66(3): 241-264$

Moldan F, Hruska J, Evans CD, Hauhs M (2012) Experimental simulation of the effects of extreme climatic events on major ions, acidity and dissolved organic carbon leaching from a forested catchment, GAyenrdsjon, Sweden. Biogeochemistry 107(1-3):455-469

Monteith DT, Stoddard JL, Evans CD, de Wit HA, Forsius M, Hogasen T, Wilander A, Skjelkvale BL, Jeffries DS, 
Vuorenmaa J, Keller B, Kopacek J, Vesely J (2007) Dissolved organic carbon trends resulting from changes in atmospheric deposition chemistry. Nature 450(7169):537-540

Nash JE, Sutcliffe JV (1970) River flow forecasting through conceptual models, part I-a discussion of principles. J Hydrol 10:282-290

Neff J, Asner G (2001) Dissolved organic carbon in terrestrial ecosystems: synthesis and a model. Ecosystems 4(1):29-48

Neff JC, Hooper DU (2002) Vegetation and climate controls on potential $\mathrm{CO}_{2}$, DOC and DON production in northern latitude soils. Glob Change Biol 8(9):872-884

Nieminen M, Koskinen M, Sarkkola S, Lauren A, Kaila A, Kiikkila O, Nieminen TM, Ukonmaanaho L (2015) Dissolved organic carbon export from harvested peatland forests with differing site characteristics. Water Air Soil Pollut 226(6): 12

Nilsson M, Sagerfors J, Buffam I, Laudon H, Eriksson T, Grelle A, Klemedtsson L, Weslien P, Lindroth A (2008) Contemporary carbon accumulation in a boreal oligotrophic minerogenic mire-a significant sink after accounting for all C-fluxes. Glob Change Biol 14(10):2317-2332

Olefeldt D, Roulet NT, Bergeron O, Crill P, Backstrand K, Christensen TR (2012) Net carbon accumulation of a highlatitude permafrost palsa mire similar to permafrost-free peatlands. Geophys Res Lett 39:L03501

Olefeldt D, Roulet N, Giesler R, Persson A (2013) Total waterborne carbon export and DOC composition from ten nested subarctic peatland catchments-importance of peatland cover, groundwater influence, and inter-annual variability of precipitation patterns. Hydrol Process 27(16):2280-2294

Oni SK, Futter MN, Teutschbein C, Laudon H (2014) Crossscale ensemble projections of dissolved organic carbon dynamics in boreal forest streams. Clim Dyn 42(9-10):2305-2321

Oulehle F, Jones TG, Burden A, Cooper MDA, Lebron I, Zielinski P, Evans CD (2013) Soil-solution partitioning of DOC in acid organic soils: results from a UK field acidification and alkalization experiment. Eur J Soil Sci 64(6):787-796

Peichl M, Oquist M, Lofvenius MO, Ilstedt U, Sagerfors J, Grelle A, Lindroth A, Nilsson MB (2014) A 12-year record reveals pre-growing season temperature and water table level threshold effects on the net carbon dioxide exchange in a boreal fen. Environ Res Lett 9(5):055006. doi:10.1088/1748-9326/9/5/055006

Raike A, Kortelainen P, Mattsson T, Thomas DN (2012) 36 Year trends in dissolved organic carbon export from Finnish rivers to the Baltic Sea. Sci Total Environ 435:188-201

Randerson JT, Chapin FS, Harden JW, Neff JC, Harmon ME (2002) Net ecosystem production: a comprehensive measure of net carbon accumulation by ecosystems. Ecol Appl 12(4):937-947

Rennermalm AK, Nordbotten JM, Wood EF (2010) Hydrologic variability and its influence on long-term peat dynamics. Water Resour Res. doi:10.1029/2009wr008242
Roulet NT, Lafleur PM, Richard PJH, Moore TR, Humphreys ER, Bubier J (2007) Contemporary carbon balance and late Holocene carbon accumulation in a northern peatland. Glob Change Biol 13(2):397-411

Ryder E, de Eyto E, Dillane M, Poole R, Jennings E (2014) Identifying the role of environmental drivers in organic carbon export from a forested peat catchment. Sci Total Environ 490:28-36

Sagerfors J, Lindroth A, Grelle A, Klemedtsson L, Weslien P, Nilsson M (2008) Annual $\mathrm{CO}_{2}$ exchange between a nutrient-poor, minerotrophic, boreal mire and the atmosphere. J Geophys Res Biogeosci 113(G01001):15. doi:10.1029/ 2006JG000306

Schlesinger WH, Andrews JA (2000) Soil respiration and the global carbon cycle. Biogeochemistry 48(1):7-20

Sulman BN, Desai AR, Schroeder NM, Ricciuto D, Barr A, Richardson AD, Flanagan LB, Lafleur PM, Tian H, Chen G, Grant RF, Poulter B, Verbeeck H, Ciais P, Ringeval B, Baker IT, Schaefer K, Luo Y, Weng E (2012) Impact of hydrological variations on modeling of peatland $\mathrm{CO}_{2}$ fluxes: results from the North American Carbon Program site synthesis. J Geophys Res Biogeosci 117:G01031. doi:10.1029/2011JG001862

Tipping E (1994) WHAM - a chemical equilibrium model and computer code for waters, sediments, and soils incorporating a discrete site/electrostatic model of ion-binding by humic substances. Comput Geosci 20(6):973-1023

Tipping E, Berggren D, Mulder J, Woof C (1995) Modelling the solid-solution distributions of protons, aluminium, base cations and humic substances in acid soils. Eur J Soil Sci 46:77-94

Tipping E, Woof C, Rigg E, Harrison AF, Ineson P, Taylor K, Benham D, Poskitt J, Rowland AP, Bol R, Harkness DD (1999) Climatic influences on the leaching of dissolved organic matter from upland UK Moorland soils, investigated by a field manipulation experiment. Environ Int 25(1):83-95

Vorren KD, Blaauw M, Wastegård S, Van der Plicht J, Jensen C (2007) High-resolution stratigraphy of the northernmost concentric raised bog in Europe: Sellevollmyra, Andøya, northern Norway. Boreas 36:253-277

Webster KL, McLaughlin JW, Kim Y, Packalen MS, Li CS (2013) Modelling carbon dynamics and response to environmental change along a boreal fen nutrient gradient. Ecol Model 248:148-164

Wu JH, Roulet NT (2014) Climate change reduces the capacity of northern peatlands to absorb the atmospheric carbon dioxide: the different responses of bogs and fens. Glob Biogeochem Cycles 28(10):1005-1024

Wu JH, Roulet NT, Nilsson M, Lafleur P, Humphreys E (2012) Simulating the carbon cycling of northern peat lands using a land surface scheme coupled to a wetland carbon model (CLASS3W-MWM). Atmos Ocean 50(4):487-506

Yu ZC (2012) Northern peatland carbon stocks and dynamics: a review. Biogeosciences 9(10):4071-4085 